DEPÓSITO LEGAL ppi $201502 Z U 4666$

Esta publicación científica en formato digital

es continuidad de la revista impresa

ISSN 0041-8811

DEPÓSITO LEGAL pp 76-654

\title{
Revista de la
}

Universidad del Turlia

Fundada en 1947

por el Dr. Jesús Enrique Lossada

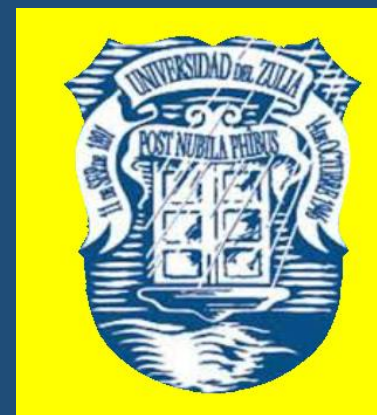

\section{Ciencias}

\section{Exactas}

Naturales

y de la Salud

\section{Aีัต 11 No $\mathbf{3 0}$ \\ Mayo - Agosto 2020 \\ Tercera ippoca \\ Maracaibo-Venezuela}




\title{
Wastewater treatment by coagulation with countercurrent sludge return
}

\author{
E.V. Alekseev *
}

ABSTRACT

Industrial wastewater contains pollutants that do not oxidize under the biological wastewater treatment conditions of populated areas. The treatment of wastewater containing persistent organic substances can be effective in its extraction. Using only water treatment separation methods does not provide sufficient efficiency. Significantly better results are obtained by combining the persistent organic pollutant coagulation method with subsequent separation processes. The disadvantage of coagulation is the need to use large doses of reagents and a large number of wastewater treatment processes. The objective of the research was to determine the possibility of reducing the doses of mineral coagulants and related reagents while maintaining sufficient efficiency in the treatment of contaminant water by countercurrent transfer of the solid phase of the sludge to the previous separation stages. . For the experimental investigation, a facility was used, which included a threesection block of sedimentation chambers, equipment for the manufacture and dosage of reagents, devices for pumping sludge and water sampling. The research was carried out in aqueous solutions of contaminants: persistent synthetic dyes used in the textile industry. The concentration of the dye solutions was assumed to be constant, equal to $150 \mathrm{mg} / \mathrm{l}$. Three series of experiments were carried out with different conditions to dose the coagulant and return the hydroxyl mud. The results of the experiments were analyzed using the Langmuir adsorption equation and the graphical constructions of the equilibrium and the lines of work of the contaminant extraction process. Compared to the traditional single-stage coagulation scheme, which includes a single addition of reagents without reusing the sludge, the use of solid-phase countercurrent transfer coagulation schemes was found, based on the research results. of sludge conductors gives a significant reduction in the number of reagents consumed and, consequently, a decrease in the amount of sludge removed.

KEYWORDS: wastewater; persistent organic pollutants; synthetic dyes; coagulation; sludge; countercurrent return.

* Moscow State University of Civil Engineering (National Research University). 


\section{Tratamiento de aguas residuales por coagulación con devolución de lodos a contracorriente}

\section{RESUMEN}

Las aguas residuales industriales contienen contaminantes que no se oxidan bajo las condiciones de tratamiento biológico de aguas residuales de áreas pobladas. El tratamiento de aguas residuales que contienen sustancias orgánicas persistentes puede ser eficaz en su extracción. El uso de solo métodos de separación de tratamiento de agua no proporciona suficiente eficiencia. Se obtienen resultados significativamente mejores al combinar el método de coagulación de contaminantes orgánicos persistentes con procesos de separación posteriores. La desventaja de la coagulación es la necesidad de utilizar grandes dosis de reactivos y una gran cantidad de procesos de tratamiento de aguas residuales. El objetivo de la investigación fue determinar la posibilidad de reducir las dosis de coagulantes minerales y reactivos relacionados al tiempo que se mantiene la eficiencia suficiente del tratamiento del agua de los contaminantes por transferencia a contracorriente de la fase sólida del lodo a las etapas previas de separación. Para la investigación experimental, se utilizó una instalación, que incluía un bloque de tres secciones de cámaras de sedimentación, equipos para la fabricación y dosificación de reactivos, dispositivos para bombear lodos y muestreo de agua. La investigación se llevó a cabo en soluciones acuosas de contaminantes: colorantes sintéticos persistentes utilizados en la industria textil. Se supuso que la concentración de las soluciones colorantes era constante, igual a $150 \mathrm{mg} / \mathrm{l}$. Se realizaron tres series de experimentos con diferentes condiciones para dosificar el coagulante y devolver el lodo de hidroxilo. Los resultados de los experimentos se analizaron utilizando la ecuación de adsorción de Langmuir y las construcciones gráficas del equilibrio y las líneas de trabajo del proceso de extracción de contaminantes. Según los resultados de la investigación, se encontró que, en comparación con el esquema tradicional de coagulación de una sola etapa, que incluye una sola adición de reactivos sin reutilizar el lodo, el uso de esquemas de coagulación con transferencia a contracorriente de la fase sólida de los conductores de lodo da una reducción significativa en el número de reactivos consumidos y, en consecuencia, una disminución en la cantidad de lodo eliminado.

PALABRAS CLAVE: aguas residuales; contaminantes orgánicos persistentes; colorantes sintéticos; coagulación; lodos; retorno a contracorriente.

\section{Introduction}

Water sphere pollution with persistent organic substances is a big problem for many countries and territories. At the same time, many organic substances are purposefully created 
REVISTA DE LA UNIVERSIDAD DEL ZULIA. 3ª época. Año 11 Nº 30, 2020

E. V. Alekseev /// Wastewater treatment by coagulation with countercurrent ...162-177

resistant to natural factors. For example, synthetic dyes, finishing preparations and other chemicals used in the production of fabrics (Kant, 2012; Majcen Le Marechal et al, 2012).

Solutions to the problem are to reduce the discharge of these substances with wastewater and to use effective methods for extracting these substances from water. Among the processes of water treatment from persistent organic substances, separation processes are the most environmentally friendly. These processes provide real water treatment as a result of the extraction of pollutants (Zaharia \& Suteu 2012; Sojkaledakowicz et al, 1998).

However, it is not possible to purify water from dissolved, colloidal and microdispersed pollutants present in the wastewater of textile and many other enterprises using separation methods.

Different methods of water treatment are used to extract these groups of pollutants (Chandrakant et al, 2016). The method of coagulation with mineral salts of metals has a wide range of applications in the treatment of municipal and industrial wastewater, including for water treatment from persistent organic pollutants (Gonzalez et al, 2007; Verma \& Kumar 2016). The main drawback of the method of water treatment by coagulation is the need to use large doses of reagents to extract pollutants. This is typical for wastewater treatment processes from persistent organic substances. High doses of coagulants and the consequent need for reagent correction of the $\mathrm{pH}$ value lead to an increase in the mineralization of treated water and an increase in sludge. In the practice of water treatment, the problem of high doses of reagents is partially solved by a combination of coagulation with methods of destruction of organic pollutants and separation processes (Sarasa et al, 1998; Alekseev 2018). The combined application of coagulation methods and separation processes increases significantly the efficiency of wastewater treatment plants. The combination of coagulation processes with separation processes has a multi-factor effect on the entire system of pollutants. This explains the versatility of combined water treatment processes (Anjaneyulu,et al, 2005; Ahmadi \& Kord Mostafapour 2017).

In wastewater coagulation processes, pollutants are extracted by reacting with slightly soluble metal hydroxides of the coagulant. According to the works of many researchers, the theory of adsorption interactions can be applied to describe the process of water treatment with mineral coagulants (Al-Qodah, 2000; Abdel-Fatah et al, 2015). 
REVISTA DE LA UNIVERSIDAD DEL ZULIA. 3ª época. Año 11 Nº 30, 2020

E. V. Alekseev /// Wastewater treatment by coagulation with countercurrent ...162-177

The Langmuir isotherm equation, which reflects the sorption process in a wide range of their concentrations, was assumed as the main equation for describing the process of extraction of pollutants (Lin \& Wang 2009; Ayari et al, 2008):

$a_{x}=A_{\infty} K_{i} X_{i} /\left(1+K_{i} X_{i}\right)$,

where $a_{\mathrm{x}}$ - specific adsorption of the extracted substance, $\mathrm{mg} / \mathrm{mg}$;

$A_{\infty}$ - the maximum adsorption (according to Langmuir), mg/mg;

$K_{i}$ - the constant of adsorption equilibrium;

$x_{i}$-equilibrium concentration, $\mathrm{mg} / \mathrm{l}$.

The transfer of the mass of pollutants from water to the surface of the solid phase of metal hydroxides formed during coagulation can be represented by the material balance equation:

$$
-2 \mathrm{~d} C=G \mathrm{~d} a_{x}
$$

where 2 - volume flow rate of wastewater, $\mathrm{m}^{3} / \mathrm{s}$;

$\mathrm{C}$ - mass concentration of pollutants, $\mathrm{kg} / \mathrm{m}^{3}$;

$\mathrm{G}$ - mass flow rate of the coagulant dosing, $\mathrm{kg} / \mathrm{s}$;

$a_{x}-$ specific adsorption of pollutants at equilibrium concentration, $\mathrm{kg} / \mathrm{kg}$.

For a single addition of a coagulant, which is common in the practice of coagulation, the dose value at known coefficients of the sorption isotherm equation can be found by integrating the material balance equation within the limits of the target water treatment problem $\left(C_{e n} ; C_{e x}\right)$ :

$$
G \int_{0}^{a_{e x}} \mathrm{~d} a_{(x)}=Q \int_{C e n}^{C e x} \mathrm{~d} C
$$

from which

$$
G a_{e x}=-2\left(C_{e x}-C_{e n}\right),
$$

where $C_{e n}$ and $C_{e x}$-concentration of pollutants in the water entering and exiting the treatment, respectively;

$a_{e x}-$ specific adsorption of pollutants corresponding to the exiting concentration $C_{e x}$. 
At ensuring the dynamic stability of the process, when the flows $\mathscr{Q}_{w}$ and $G$ are constant in value, equation (3) takes the form:

$$
G / Q=\left(C_{e n}-C_{e x}\right) / a_{e x}
$$

Expression (4) represents the equation of the working line of the pollutant extraction process, and the ratio $G / Q$ is the specific flow rate of the coagulant, that is, its dose. It follows that in order to achieve the required concentration of pollutants in treated water $C_{e x}$ by limiting indicator, the required dose of coagulant, $D_{c}$, can be determined by the expression: $D_{c}=\left(C_{e n}-C_{e x}\right) / a_{e x}$, where $D_{c}$-dose of coagulant.

According to expression (5), the required dose of coagulant is determined for the minimum value of specific adsorption corresponding to the minimum concentration of pollutants in the water after its treatment. This necessitates the use of large doses of coagulants and related reagents.

Theoretically, reducing the required dose of reagents can be achieved by increasing the specific adsorption and reducing the difference between the initial and final concentrations of pollutants. This is possible by ensuring multiple contacts of wastewater with the sorption surface of the formed hydroxyl sludge with a constant increase in the equilibrium concentration.

One way to achieve this result may be to transfer repeatedly and add the resulting sludge to the treated water in the direction opposite to the movement of the water.

Countercurrent transfer of the formed sludge can be repeated. In this case, it is necessary to assign intervals of change in the concentration of pollutants $\left(\Delta C=C_{n}-C_{n-1}\right)$, and the integration of equation (2) to perform within the specified intervals of concentrations of pollutants:

$$
-Q \int_{C_{n-1}}^{C_{n}} \mathrm{~d} C=G \int_{a_{n-1}}^{a_{n}} \mathrm{~d} a_{(x)}
$$

If the flows $\mathscr{Q}_{w}$ and $G$ are constant in a given range of concentrations of removed pollutants $(\Delta C)$, we come to the following expression:

$$
-G / Q=\left(C_{n-1}-C_{n}\right) /\left(a_{n-1}-a_{n}\right),
$$


where $a_{n-1}$ and $a_{n}$ - values of specific adsorption of pollutants at equilibrium concentrations $C_{n}$ and $C_{n-1}$, respectively;

$n$ - number of separation stages; $(n-1)$ - number of sludge transfers.

Formula (7) is an equation of the section of the working line of the coagulation process at a given range of concentrations of pollutants $\Delta C$, and the ratio $G / 2$ is the average dose of the coagulant at this interval.

It follows that within each separation stage, the dose of coagulant required at each separation stage can be determined by the equation:

$$
\begin{gathered}
D_{c}=-\left(C_{n-1}-C_{n}\right) /\left(a_{n-1}-a_{n}\right), \\
\text { here } \quad C_{n}=C_{e x} \text { and } a_{n}=a_{e x}
\end{gathered}
$$

However, the final analytical solution of equation (8) presents difficulties due to the interdependence of $C_{n}$ and $a_{n}$ at specific separation stages.

The aim of the research was to determine the possibility of reducing the doses of mineral coagulants and related reagents while maintaining sufficient efficiency of water treatment from pollutants by countercurrent transfer of the solid phase of the sludge to the previous stages of separation.

The objectives of the experimental research included the following:

Carrying out the process of extraction of pollutants with a single introduction of a coagulant and confirmation of the possibility of using the Langmuir isotherm to describe the quantitative relationship between the dose of the reagent and the amount of extracted pollutants;

Determining the coefficients of the Langmuir equation;

Carrying out the process of extraction of pollutants using the principle of countercurrent transfer of sludge containing aluminum hydroxide;

Analysis of the results of coagulation according to the scheme of countercurrent transfer of the solid phase of the resulting sludge containing aluminum hydroxide.

\section{Materials and methods}

Studies were conducted on aqueous solutions containing persistent organic pollutants. Persistent synthetic dyes used in the textile industry were selected as such substances (pollutants). The concentration of dye solutions was assumed to be constant, 
equal to $150 \mathrm{mg} / \mathrm{l}$, which corresponded to the average value of their content in the wastewater of textile dyeing plants.

Determination of the dye concentration was carried out by colorimetric method using a photometer UNICO 2800. Aluminum sulfate was used as a mineral coagulant.

Experimental studies were performed on a model of a flow facility. The scheme of the experimental facility is shown in Fig. 1.

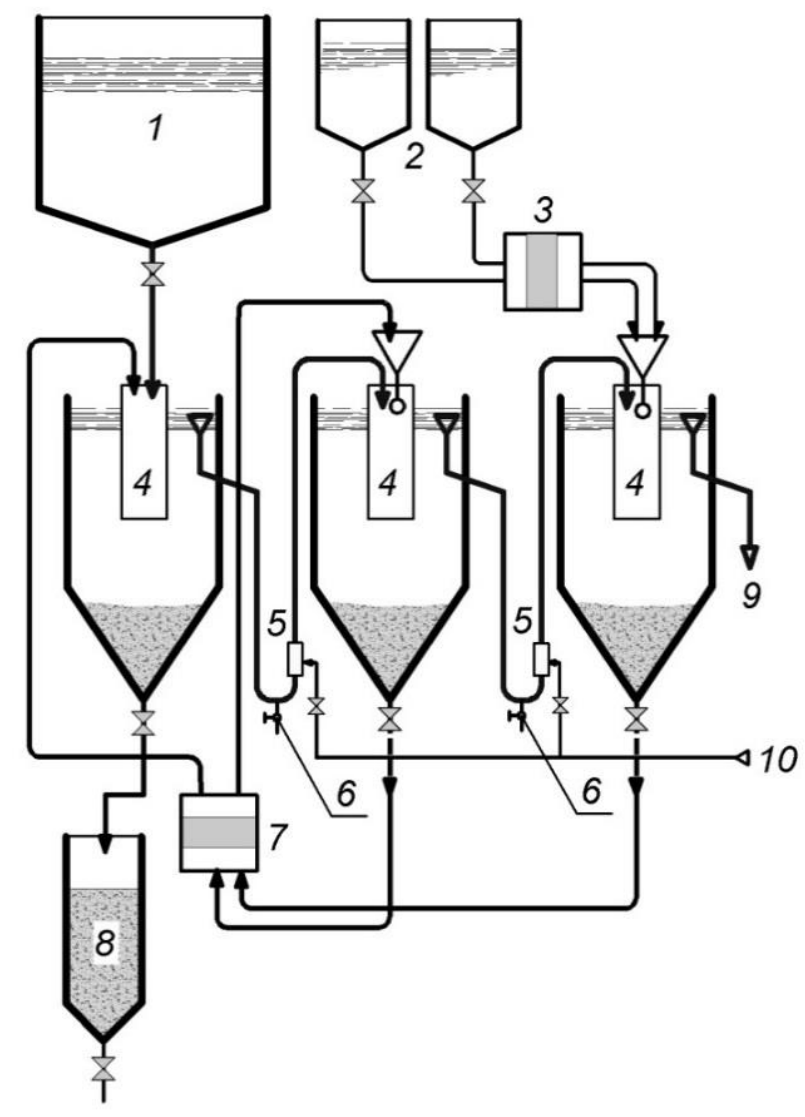

Fig.l. Experimental facility model: 1 - feed tank; 2 - tanks for the preparation of reagent solutions; 3, 7 -peristaltic pumps; 4 - chambers for settling; 5 - airlifts; 6 - samplers; 8 - a container for collecting sludge; 9 - treated water; 10 - air supply.

The main stage of separation of aluminum hydroxide sediment and adsorbed dyes formed in the process of coagulation was adopted by the model of sedimentation tank with a vertical movement of the water flow. The choice of a model of this type of equipment is determined by the simplicity of design, clarity of the process of formation and separation of the precipitate hydroxyl, a relatively small sludge moisture content and possibility of use under field conditions. 
REVISTA DE LA UNIVERSIDAD DEL ZULIA. 3ª época. Año 11 Nº 30, 2020

E. V. Alekseev /// Wastewater treatment by coagulation with countercurrent ...162-177

The facility included three identical chambers for settling, connected in series by means of airlift devices. The design of the airlift devices made it possible to take water samples, and maintain a predetermined position of the water level in the next settling chamber.

The test water came from a feed tank. Maintaining a given dose of coagulant during the experiment was achieved by proportional supply of solutions of coagulant and alkali. Multi-channel peristaltic pumps were used as proportional feeders. The concentration of the alkali solution was pre-selected according to the concentration of the working solution of the coagulant under the condition of maintaining the required $\mathrm{pH}$ value in their mixture. At the facility, it was possible to study the treatment of water with different schemes of transfer of the solid phase of the resulting sediment.

The methodological basis of the experiments included three series of experiments.

In the first series of experiments, the coagulation of the test water was carried out in contact (without a flow) mode with constant fixed doses of reagents (coagulant and neutralizer, if necessary, $\mathrm{pH}$ control), introduced into the first settling chamber. The coagulant doses were varied from 20 to $250 \mathrm{mg} / \mathrm{l}$ calculated from anhydrous salt. After that, the water was not stirred for 30 minutes. The subsequent chambers of settling (the second and third) were not used in this series of experiments. The sludge was being dumped.

The second and third series of experiments were carried out in flow mode on water. Water was supplied to the beginning of the facility, passing successively all the settling chambers. Reagents were continuously added to the third settling chamber. Doses of coagulant in specific experiments varied in the range of $50 . . .250 \mathrm{mg} / \mathrm{l}$ on anhydrous salt in increments of $50 \mathrm{mg} / \mathrm{l}$.

In the second series of experiments, coagulation was carried out according to a twostage scheme. The sludge that falls in the third settling chamber is pumped to the second settling chamber along with the incoming water. The sludge from the second settling chamber was discharged. Water samples were taken at the end of the facility and from the airlift device of the second settling section to determine the residual concentration of pollutants (dyes).

The third series of experiments was conducted on a three-stage scheme. The difference was that the sludge from the second chamber was pumped to the distribution device of the 
REVISTA DE LA UNIVERSIDAD DEL ZULIA. $3^{a}$ época. Año $11 N^{\circ}$ 30, 2020 E. V. Alekseev /// Wastewater treatment by coagulation with countercurrent ...162-177

first settling chamber, which received water from the feed tank. The sludge from the first chamber was discharged.

Water samples were taken at the end of the installation and from the airlift devices of the first and second settling sections.

\section{Results and Discussion}

The results of the first series of experiments on a single-stage scheme with a single use of a coagulant are shown in table 1 and in Fig. 2.

Tablel: Indicators of water treatment from dyes on a single-stage scheme with a single coagulation without the use of sludge

\begin{tabular}{|l|l|l|l|}
\hline Dc, mg/l & Cex, $\mathrm{mg} / \mathrm{l}$ & Cen - Cex, mg/l & al, mg/mg \\
\hline 0 & 150 & 0 & 0 \\
\hline 20 & 130 & 20 & 0,99 \\
\hline 35 & 118 & 32 & 0,97 \\
\hline 50 & 101 & 49 & 0,98 \\
\hline 100 & 69 & 81 & 0,81 \\
\hline 150 & 45 & 105 & 0,70 \\
\hline 200 & 29 & 121 & 0,61 \\
\hline 250 & 22 & 128 & 0,51 \\
\hline
\end{tabular}

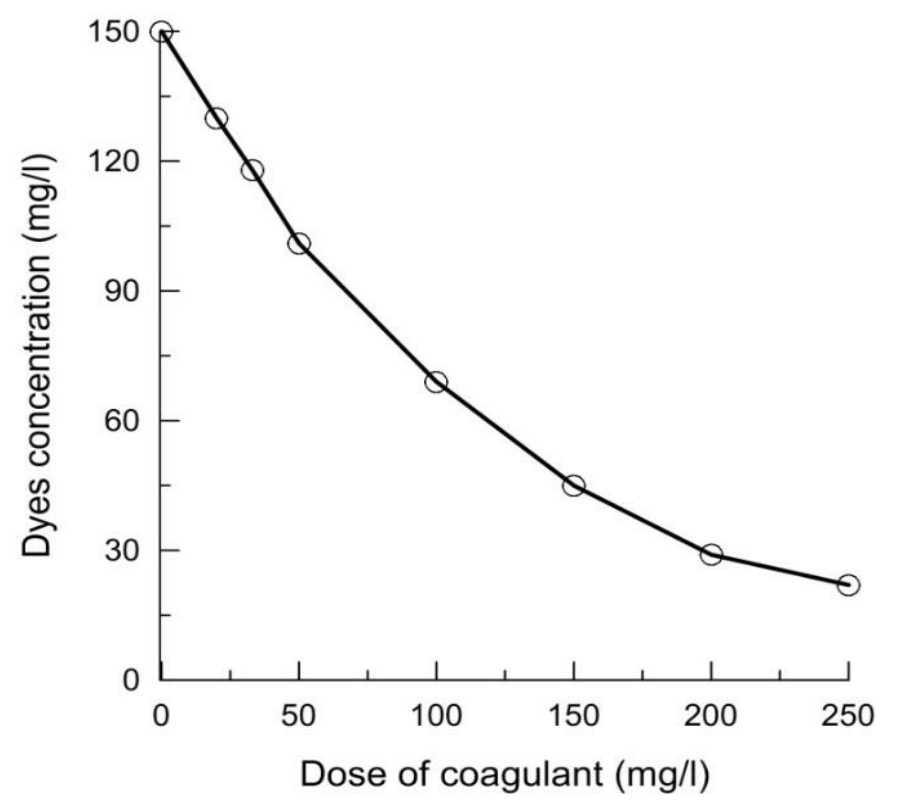

Fig. 2. Effect of the coagulant dose on reducing the dye content 
The obtained values of residual dye concentrations with a single introduction of the coagulant are approximated by the Langmuir equation.

As a result of processing the experimental data, the values of the constants of the Langmuir isotherm equation were determined: $\mathrm{a} \square=1.234$ and $\mathrm{Ki}=0.0323$. Accordingly, the Langmuir isotherm equation (f. 1 ) for this process will have the form:

$$
\mathrm{ax}=0,04 \mathrm{Xi} /(1+0,0323 \mathrm{Xi}) \text {, }
$$

A graphical interpretation of the Langmuir isotherm is shown in Fig. 3.

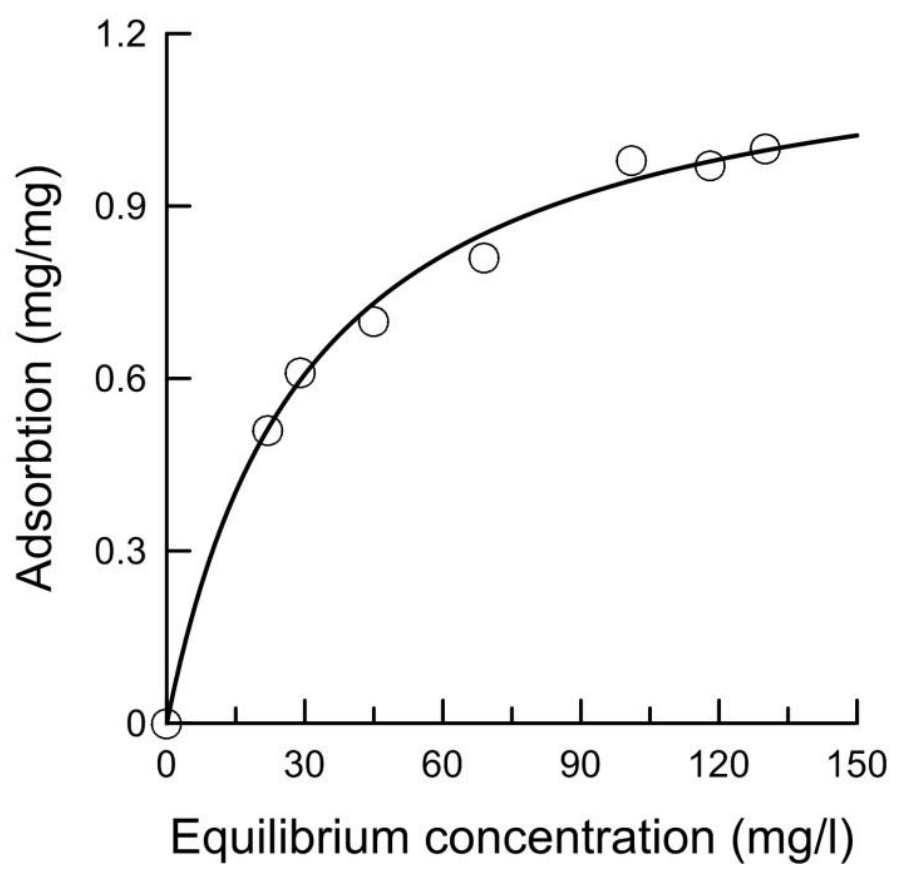

Fig.3. The effect of the equilibrium concentration on the specific adsorption of dyes (according to Langmuir)

The view of the isotherm line confirms the adsorption mechanism of dye extraction. The solution to the water treatment objective is to extract pollutants as much as possible. Therefore, their equilibrium concentration will be minimal. The isotherm shows that the minimum value of the equilibrium concentration will also correspond to the minimum value of the specific adsorption.

According to the results of the experiments given in table 1 and the values of the Langmuir isotherm constants the equilibrium line equation for this coagulation process was obtained: 
REVISTA DE LA UNIVERSIDAD DEL ZULIA. 3ª época. Año 11 Nº 30, 2020

E. V. Alekseev /// Wastewater treatment by coagulation with countercurrent ...162-177

$$
\mathrm{Xi}=1,548 \square 104 \mathrm{ax} / \text { (617-500 ax), }
$$

where $\mathrm{Xi}$ - equilibrium concentration of dyes in water, $\mathrm{mg} / \mathrm{l}$;

ax - specific adsorption of dyes, $\mathrm{mg} / \mathrm{mg}$, at equilibrium concentration.

The equilibrium line (curve 1) establishes the relationship between the content of the extracted substance (sorptive) in water and on the solid surface of the sediment (sorbate).

For single-stage coagulation of a dye solution with a fixed dose of $150 \mathrm{mg} / \mathrm{l}$ coagulant (see table 1) the equilibrium and working lines of the process are constructed, which are shown in Fig. 4.

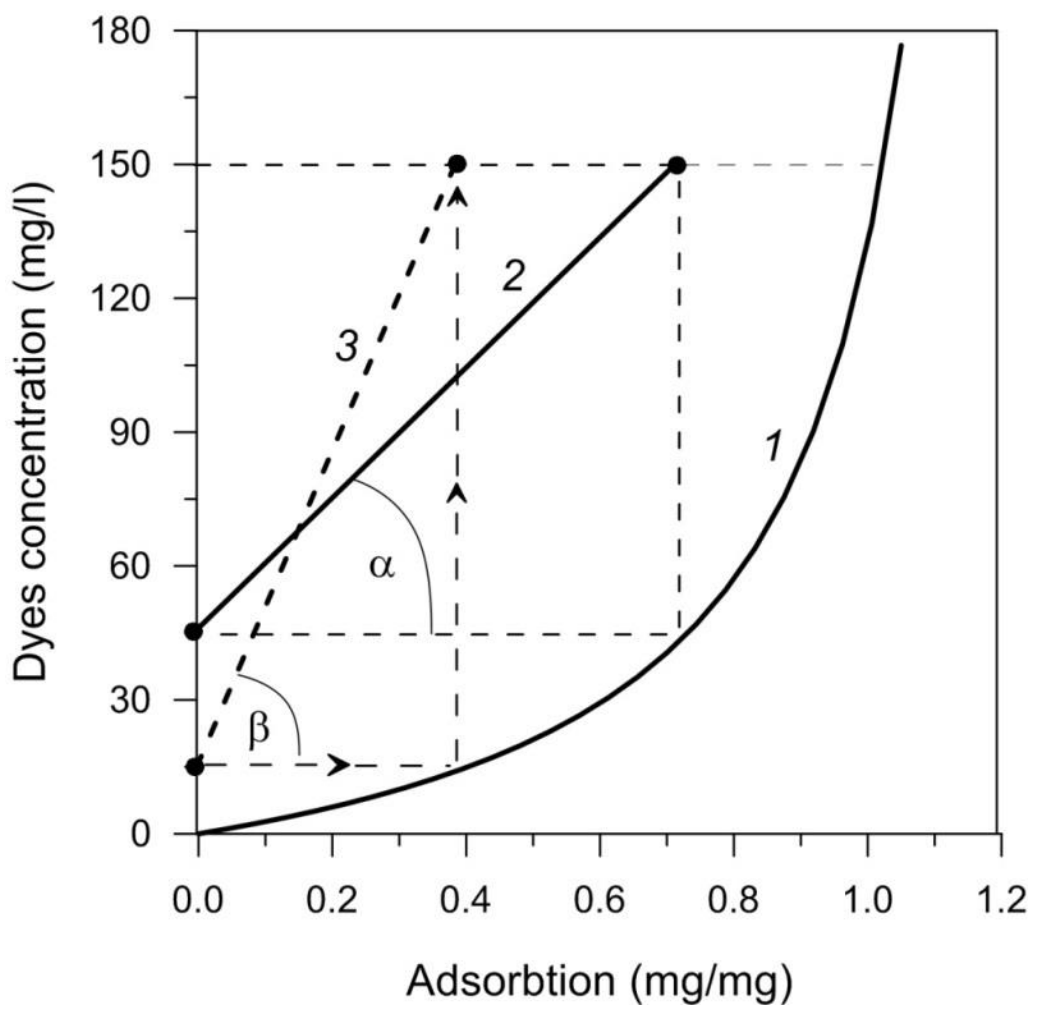

Fig.4. Lines of single-stage process of coagulation of dyes: 1 - the equilibrium line of the process; 2 - working line of single coagulation process with dose $\mathrm{Dc}=150 \mathrm{mg} / \mathrm{l} ; 3$ - working line of single coagulation process with dose $\mathrm{Dc}=330 \mathrm{mg} / \mathrm{l}$.

The working line of the coagulation process (curve 2) establishes the relationship between the initial content of pollutants and their concentration in treated water at a given dose of coagulant. In accordance with equation (8), the slope of the working line at an angle (D) sets the value of the required dose of coagulant. Accordingly, the dose of the coagulant is equal to the tangent of the angle of inclination of the working line. 
REVISTA DE LA UNIVERSIDAD DEL ZULIA. 3ª época. Año 11 Nº 30, 2020

E. V. Alekseev /// Wastewater treatment by coagulation with countercurrent ...162-177

In the general case of water treatment by coagulation, the specific adsorption of pollutants ( $\mathrm{Cc} / \mathrm{Dc}$ ) theoretically cannot be below the equilibrium line for the corresponding equilibrium concentration. However, the approximation of the working line to the equilibrium one characterizes the greater completeness of the use of the coagulant.

In the first series of experiments the initial value of the working line of a single-stage coagulation (curve 2) is arranged on the concentrations of the dyes at the end of the process Cex $=45 \mathrm{mg} / \mathrm{l}$, which corresponds to the value of specific adsorption by the formula (9), equal to $0.72 \mathrm{mg} / \mathrm{mg}$. This leads to low utilization of the sorption capacity of hydroxyl sludge coagulant. In practice, this means that if you need to implement a deeper water treatment, you will need significantly higher doses of reagents. For example, the process of water treatment of a similar composition, up to the value Cex $=15 \mathrm{mg} / 1$, is illustrated by a working line (curve 3), located at an angle which corresponds to an increase in the required dose of coagulant to $330 \mathrm{mg} / \mathrm{l}$.

The results of the second and third series of experiments with the return of sludge, conducted under flowing conditions, are shown in tables 2 and 3.

Table 2. Indicators of water treatment from dyes in a two-stage scheme with a single countercurrent transfer of sludge

\begin{tabular}{|l|l|l|l|l|l|l|}
\hline \multirow{2}{*}{$\begin{array}{l}\text { The dose of coagulant, } \\
\text { Dc, mg/l }\end{array}$} & \multicolumn{3}{l}{ Settling chambers } \\
\cline { 2 - 8 } & $\begin{array}{l}\text { The lst chamber } \\
\text { Cex(l), } \\
\mathrm{mg} / \mathrm{l}\end{array}$ & $\begin{array}{l}\mathrm{a}(\mathrm{l}), \\
\mathrm{mg} / \mathrm{mg}\end{array}$ & $\begin{array}{l}\text { Tex(2), } \\
\mathrm{mg} / \mathrm{l}\end{array}$ & $\begin{array}{l}\mathrm{a}(2), \\
\mathrm{mg} / \mathrm{mg}\end{array}$ & $\begin{array}{l}\text { Cex(3), } \\
\mathrm{mg} / \mathrm{l}\end{array}$ & $\begin{array}{l}\mathrm{a}(3), \\
\mathrm{mg} / \mathrm{mg}\end{array}$ \\
\hline 50 & 150 & - & 150 & - & 102,0 & 0,97 \\
\hline 100 & 150 & - & 127 & 0,99 & 51,0 & 0,77 \\
\hline 150 & 150 & - & 81 & 0,89 & 16,6 & 0,43 \\
\hline 200 & 150 & - & 44 & 0.72 & 5,6 & 0,19 \\
\hline 250 & 150 & - & 28 & 0,59 & 2,8 & 0,10 \\
\hline
\end{tabular}

Table 2 shows the results of coagulation of a mixture of dyes with an initial concentration of $150 \mathrm{mg} / \mathrm{l}$. Doses of aluminum sulfate were changed in the range from 50 to $250 \mathrm{mg} / \mathrm{l}$. Coagulation was carried out according to a two-stage scheme with a single 
REVISTA DE LA UNIVERSIDAD DEL ZULIA. 3ª época. Año 11 Nº 30, 2020

E. V. Alekseev /// Wastewater treatment by coagulation with countercurrent ...162-177

countercurrent transfer of the sludge to the second chamber. In the first chamber, the water was not treated.

The results of coagulation of water with a dose of $50 \mathrm{mg} / \mathrm{l}$ for all schemes of introduction of reagents are almost identical. Reducing the concentration of pollutants to the dose of coagulant $\mathrm{QC} / \mathrm{Dc} \mathrm{Dl}$, which means approaching the theoretically possible value of adsorption. This means that the dose of coagulant in this case is insufficient for effective removal of dyes. Increasing the dose of coagulant to $250 \mathrm{mg} / \mathrm{l}$ leads to a significant (more than 18 times) decrease in the content of dyes in purified water. At the same time, the potential stock of the sorption capacity of the hydroxides remains high. This explains the significant effect of reducing the dye content after the second settling chamber.

Carrying out the coagulation process using a three-stage scheme with two-fold transfer of the solid phase of the sediment using a countercurrent scheme has demonstrated the possibility of reducing significantly the consumption of reagents at comparable doses and achieving significant efficiency of water treatment (table 3). For example, coagulation with a dose of $\mathrm{Dc}=150 \mathrm{mg} / \mathrm{l}$ with a single transfer of the sludge reduces the dye content to 16.6 $\mathrm{mg} / \mathrm{l}$. Coagulation with a double transfer of the sludge under similar conditions reduces the dye content to $6.5 \mathrm{mg} / \mathrm{l}$.

The analysis of the results shown in table 3 shows that the sorption capacity of the aluminum hydroxide precipitate is used almost completely during two-fold countercurrent transfer of the solid phase of the sediment. Comparison of the results of coagulation in the range of doses Dc (150...200) $\mathrm{mg} / \mathrm{l}$ with coagulation on a single-stage scheme (see table 1) fully confirms the advantages of the technology of countercurrent transfer of hydroxyl precipitation of coagulation both in terms of efficiency of water treatment and in terms of reagent consumption.

The use of a coagulant dose of more than $200 \mathrm{mg} / \mathrm{l}$ provides a deep extraction of pollutants from the water. However, the sorption capacity of the sediment is not completely exhausted. In this case, it can be assumed that adding another solid phase transfer stage to the coagulation process scheme will increase the efficiency of water treatment at the same doses of coagulant. With equal efficiency of water treatment, it is possible to reduce the dose of reagents. This can be explained by a more complete use of the precipitation sorption capacity. 
REVISTA DE LA UNIVERSIDAD DEL ZULIA. 3ª época. Año 11 Nº 30, 2020

E. V. Alekseev /// Wastewater treatment by coagulation with countercurrent ...162-177

Table 3: Indicators of water treatment from dyes according to a three-stage scheme with double countercurrent sludge transfer

\begin{tabular}{|c|c|c|c|c|c|c|}
\hline \multirow{3}{*}{$\begin{array}{l}\text { The dose of coagulant, } \\
\text { Dc, mg/l }\end{array}$} & \multicolumn{6}{|c|}{ Sedimentation tank sections } \\
\hline & \multicolumn{2}{|c|}{ The lst chamber } & \multicolumn{2}{|c|}{ The 2nd chamber } & \multicolumn{2}{|c|}{ The 3rd chamber } \\
\hline & $\begin{array}{l}\operatorname{Cex}(1) \\
\mathrm{mg} / \mathrm{l}\end{array}$ & $\begin{array}{l}\mathrm{a}(\mathrm{l}) \\
\mathrm{mg} / \mathrm{mg}\end{array}$ & $\begin{array}{l}\operatorname{Cex}(2), \\
\mathrm{mg} / \mathrm{l}\end{array}$ & $\begin{array}{l}\mathrm{a}(2) \\
\mathrm{mg} / \mathrm{mg}\end{array}$ & $\begin{array}{l}\operatorname{Cex}(3) \\
\mathrm{mg} / \mathrm{l}\end{array}$ & $\begin{array}{l}\mathrm{a}(3) \\
\mathrm{mg} / \mathrm{mg}\end{array}$ \\
\hline 50 & 150 & - & 147 & 0,99 & 100 & 0,94 \\
\hline 100 & 146 & 0,99 & 123 & 0,98 & 48 & 0,75 \\
\hline 150 & 109 & 0,96 & 38,6 & 0,68 & 6,5 & 0,21 \\
\hline 200 & 47 & 0,75 & 7,2 & 0,23 & 0,82 & 0,032 \\
\hline 250 & 29 & 0,59 & 3,2 & 0,12 & 0,29 & 0,011 \\
\hline
\end{tabular}

Figure 5 shows the curves of the equilibrium and working lines of the coagulation process using two-stage and three-stage coagulation schemes.

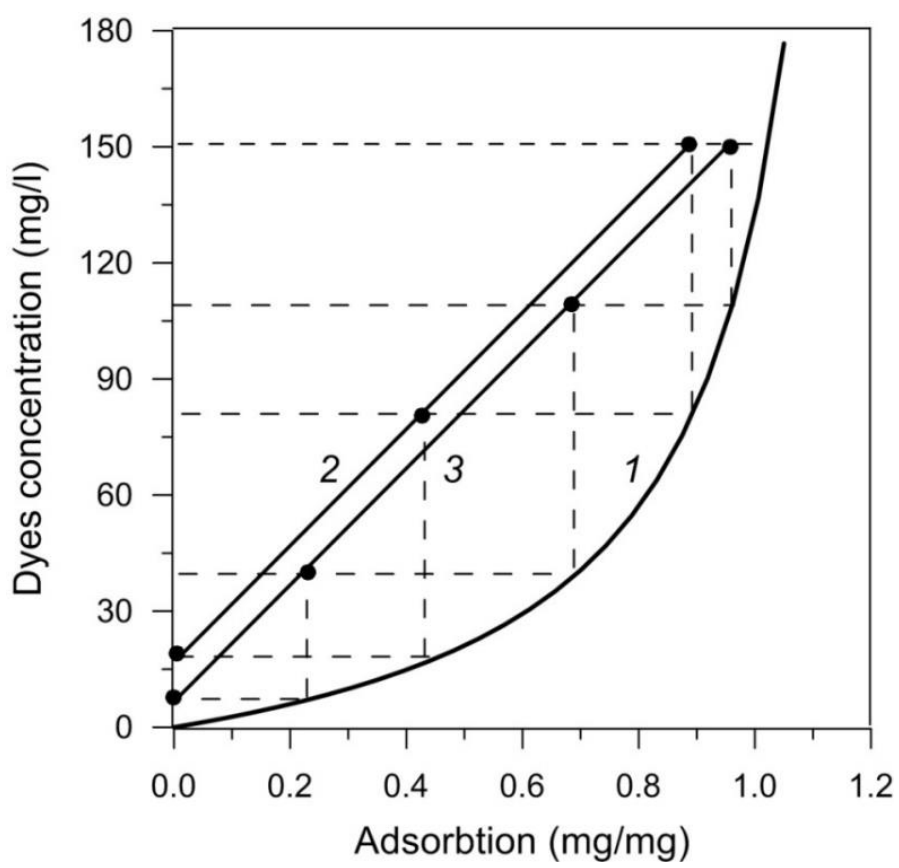

Fig.5. Lines of process of water treatment from dyes on two-stage and three-stage schemes of coagulation: 1 - equilibrium line of the coagulation process; 2 - working line of the coagulation process with a dose of $\mathrm{Dc}=150 \mathrm{mg} / \mathrm{l}$ with a single countercurrent transfer of sludge; 3 - working line of the coagulation process with a dose of $\mathrm{Dc}=150 \mathrm{mg} / \mathrm{l}$ with double countercurrent transfer of sludge. 
REVISTA DE LA UNIVERSIDAD DEL ZULIA. 3ª época. Año 11 Nº 30, 2020

E. V. Alekseev /// Wastewater treatment by coagulation with countercurrent ...162-177

Coagulation using a two-stage scheme with a single countercurrent transfer of sludge (working line 2, Fig.5) significantly exceeds the depth of water treatment according to a single-stage scheme (working line 1, Fig. 4). According to the single-stage scheme, this result could only be obtained at a dose of coagulant Dc=330 mg/l (Fig.4).

Parallel displacement of the working line of the three-stage coagulation process with a two-time transfer of the sludge towards the equilibrium line (Fig. 5, line 3) corresponds to a greater depth of water treatment and greater completeness of the sorption capacity of the hydroxyl precipitate at the same dose of coagulant.

Conclusion

The results of studying different schemes of the coagulation process show that with a lack of reagents, the specific adsorption of pollutants approaches the theoretical limit. In this case, the complication of the scheme of the coagulation process cannot increase its effectiveness. At the same time, with an excessive dose of coagulant, the greatest efficiency of water treatment is achieved with a finite number of separation stages with the return of the solid phase of the sludge. Further complication of the scheme of the coagulation process does not lead to an increase in the efficiency of water treatment.

The conducted research confirmed the possibility of a significant increase in the efficiency of coagulation processes and other methods of water treatment, the regularities of which are described by the Langmuir isotherm equation. This can be achieved by applying several steps of coagulation with a countercurrent transfer of the sludge. Compared to coagulation by traditional single-stage scheme, including a single addition of reagents without recycling sludge, the use of schemes of coagulation with a countercurrent transfer of the solid phase of the sediment leads to a significant reduction in the consumption of reagents and, accordingly, decreases the quantity of diverted sludges

\section{References}

Abdel-Fatah M. A., Sherif H.O., Agour F., Hawash S. I. (2015). Textile waste water treatment by chemical coagulation technology. - Global Journal of Advance Engineering Technology and Sciences. No.2(12). Pp.20-28.

Ahmadi S., Kord Mostafapour, F. (2017).Treatment of Textile wastewater using a combined Coagulation and DAF processes, Iran, 2016.- Arch Hyg Sci.Vol.6, No.3. pp.229-234. 
REVISTA DE LA UNIVERSIDAD DEL ZULIA. 3ª época. Año 11 Nº 30, 2020

E. V. Alekseev /// Wastewater treatment by coagulation with countercurrent ...162-177

Alekseev E.V. (2018). Abatement of environmental pollution by effluents of textile industry. - Pollution Research, Vol. 37 (1). Pp. 278-284.

Al-Qodah Z. (2000). Adsorption of dyes using shale oil ash. - Water Research, No.34 pp. 4295-4303.

Anjaneyulu,Y., Sreedhara Chary N., Suman Raj D.S. (2005). Decolourization of industrial effluents - available methods and emerging technologies - a review. - Reviews in Environmental Science and Bio/Technology, Vol.4, pp. 245-273.

Ayari F., Srasra E., Trabelsi-Aydi M. (2008), Low-cost adsorbents for a dye uptake from contaminated water modeling of adsorption isotherms: the Langmuir, Freundlich and Elovich models. - Surface Engineering and Applied Electrochemistry, No.6, pp. 76-86.

Chandrakant R. Holkar, Ananda J. Jadhav, Dipak V. Pinjari, Naresh M. Mahamuni, Aniruddha B. Pandit (2016). A critical review on textile wastewater treatments: Possible approaches. - Journal of Environmental Management. Vol. 182. pp.351-366.

Gonzalez T., Dominguez J., Beltran-Heredia J., Garcia H., Snachez-Lavado F. (2007). Aluminum sulfate as coagulant for highly polluted cork processing wastewater: evaluation of settleability parameters and design of a clarifier-thickener unit. - Journal of Hazardous Materials. Vol.148. pp 6-14.

Kant R. (2012). Textile dyeing industry an environmental hazard. - Natural Science. Vol.4 No.l, pp. 22-26.

Lin J.X., Wang L. (2009). Adsorption of dyes using magnesium hydroxide-modified diatomite. - Desalination and Water Treatment. No.8, pp.l-9.

Majcen Le Marechal A., Krianec B., Vajnhandl S., Volmajer J. (2012). Textile Finishing Industry as an Important Source of Organic Pollutants. Organic pollutants ten years after the Stockholm Convention - Environmental and Analytical Update.- InTech, pp. 26-54.

Sarasa J., Roche M.P., Ormad M.P., Gimeno E., Puig A., Ovelleiro J.L. (1998). Treatment of wastewater resulting from dye manufacturing with ozone and chemical coagulation. - Water Research Vol.32, No.9, pp. 2721-2727.

Sojkaledakowicz J., Koprowski T., Machnowski W., Knudsen H. (1998). Membrane filtration of textile dyehouse wastewater for technological water reuse. - Desalination. Vol. 119, (1-3). Pp. 1-10.

Verma M., Kumar R.N. (2016). Can coagulation-flocculation be an effective pre-treatment option for landfill leachate and municipal wastewater co-treatment? - Perspectives in Science .Vol. 8, September, pp. 492-494.

Zaharia C., Suteu D. (2012). Textile organic dyes-characteristics, polluting effects and separation/elimination procedures from industrial effluents - a critical overview. - Organic pollutants ten years after the Stockholm Convention - Environmental and Analytical Update.- InTech, pp. 55-86. 